\title{
POLITIK DAKWAH DAN DAKWAH POLITIK DI ERA REFORMASI INDONESIA
}

\author{
Andi Rosa \\ IAIN Sultan Maulana Hasanuddin Banten \\ e-mail: andi762076@yahoo.co.uk
}

\begin{abstract}
This research activity parse Dzikir majlis Susilo Bambang Yudhoyono (SBY) "Nurussalam" which has a strategic role in the democratic era. His status as a society organizations (NGOs) are positioned optimally by interest groups, political organizations and even into the container. By analyzing the dataobtained through interviews and documentation, the results of this study indicate that this council makes verses of the Qur'an that deals with the concept of al-'ummah, alukhuwwah al-islamiyya, and al-ta'äwun as a cornerstone in interpreting paragraph integrative social which is then used as a propaganda entity. Proselytizing as mass communication, political communication line with more likely to use communication as a way to mobilize the masses massif. Even activities have been able to carry out the functions of political propaganda as part of the interest-group system.

Penelitian ini berusaha untuk mengurai kegiatan Majelis Dzikir Susilo Bambang Yudhoyono (SBY) "Nurussalam" yang memiliki peran strategis di era reformasi. Statusnya sebagai organisasi masyarakat (Ormas) diposisikan secara maksimal oleh kelompok kepentingan, bahkan menjadi wadah lembaga politik. Dengan mengganalisis data yang diperoleh melalui wawancara dan dokumentasi, hasil penelitian ini menunjukkan bahwa majlis ini menjadikan ayat al-Qur'an yang berkaitan dengan konsep al-ummah, al-ukhuwwah al-islämiyyah, dan al-ta'āwun sebagai landasan dalam menafsirkan ayat sosial integratif yang kemudian dijadikan sebagai sebuah entitas dakwah. Dakwah sebagai komunikasi massa, sejalan dengan komunikasi politik yang lebih cenderung memanfaatkan komunikasi sebagai cara massif untuk menggalang massa. Bahkan kegiatannya telah mampu melaksanakan fungsi politik dakwah sebagai bagian dari sistem interest-group.
\end{abstract}

Keywords: tafsir integratif, kampanye politik, majelis dzikir, interestgroup 


\section{A. Pendahuluan}

Relasi agama dan Negara, dewasa ini di Indonesia khususnya, lebih dominan bersifat substantif. Namun — di sisi lain — menurut Firmanzah, fenomena praktik politik telah memberikan citra mengenai politik yang buruk di masyarakat. Politik berkonotasi persengkongkolan, intrik, penghianatan dan lain di bibir lain di hati. ${ }^{1}$ Memang sejak munculnya modernisasi dalam kehidupan beragama, yang ditandai dengan dominasi ilmu-ilmu empirik, muncullah dikotomi antara kebenaran ilmu pengetahuan dengan kebenaran berdasarkan agama. Bahkan berlanjut kepada dekadensi moral dan kekacauan kemanusiaan (dalam bahasa agama: fitnah). ${ }^{2}$ Karena itu, bagi para praktisi politik, berpolitik sering kali melupakan nilai-nilai positif dari filsafat politik, yang didefinisikan oleh S.P. Varma bahwa filsafat politik adalah "usaha yang sungguh-sungguh untuk mengetahui sifat politik dan kebenaran, atau tatanan politik yang bagaimana yang dianggap baik" ${ }^{3}$

Berbeda dengan aktivitas kampanye Islam politik yang dilakukan oleh capres Susilo Bambang Yudhoyono (SBY), saat pemilu 2004 dan 2009 yang nampak lebih mengedepankan nilai-nilai substansi Islam dengan mendirikan "Majelis Dzikir Nurussalam SBY". Tetapi di sisi lain, sering dituduh tidak islami, misalnya karena dianggap sang istri calon Presiden -saat berkampanye- tidak mengenakan jilbab dalam kesehariannya. Sebuah fenomena yang menarik untuk diteliti jika ditinjau dari sisi etika politik dan substansi ajaran agama dalam konstruksi Tafsir Ayat Sosial Integratif (TASIF). ${ }^{4}$

\footnotetext{
1Lihat:, Firmanzah, Marketing Politik antara Pemahaman dan Realitas, (Jakarta: Yayasan Obor Indonesia, 2008), h. 132.

2Dadang Kahmad, Sosiologi Agama, (Bandung; Rosda Karya, 2006), h.194.

3Lihat: S.P.Varma, Teori Politik Modern, (Jakarta: RajaGrafindo Persada, 2007), h.154-155.

${ }^{4}$ Sebuah metode tafsir yang mencoba mengkolaborasikan antara paradigma ilmiah (scientific paradigm) dengan paradigma tafsir al-Qur'an. Hasan Hanafi menyatakan, bahwa tafsir al-Qur'an yang benar adalah tafsir yang merupakan anak zamannya dengan ditandai adanya pergumulan kekuatan sosial, dan mengkaji teks mengharuskan memahami psikologi sosial. Lihat: Hasan Hanafi, Metode Tafsir dan Kemaslahatan Umat, (Nawesea Press: Jogjakarta, 2007), diterjemahkan dari Manāhij al-Tafsïr wa Mașālih al-ummah dan dari makalah "Qaḍāyā 'Arābiyah," h. 69 \& 72. Idealnya langkah-langkah tafsir Integratif, adalah sebagai berikut: a) Menentukan fokus tema; b) Memahami filsafat ilmu dari topik tema/permasalahan; c) Melakukan riset lapangan atau laboratorium tentang topik tema (jika diperlukan); d) Menentukan ayat-ayat yang relevan dengan tema; e) Memilah metode tafsir ayat yang relevan (metode tahlili/analisis ayat, tematik, semantik, atau hermeneutik) dengan tujuan tema; f) Melakukan analisis penafsiran dengan pendekatan teori ilmiah terkait tema, g) Melakukan dialog interpretasi kontekstual dengan memperhatikan tiga fungsi/tujuan dalam tafsir integratif (al- tabyīn, al i'jäz, atau istikhrāj al-'ilmi). Makna al-tabyīn adalah menjelaskan ayat dengan memanfaatkan ilmu dan
} 
Penafsiran ayat al-Qur'an terkait tema relasi politik, dalam konteks kegiatan Majelis Dzikir SBY “Nurussalam”, dapat dipilah sebuah sub tema penting, yaitu: Majelis Dzikir SBY “Nurussalam" sebagai Kelompok Kepentingan (Interest Group) di Era Reformasi.

\section{B. Sekilas Kegiatan Majelis Dzikir "Nurussalam" Susilo Bambang Yudhoyono di Jakarta Menjelang Pemilu 2004 dan 2009}

Yayasan Majelis Dzikir "Nurussalam" Susilo Bambang Yudhoyono (SBY) berdiri pada tahun 2005 di Jl. Asem Baris No. 13 A, Jakarta Selatan. Pada awalnya Yayasan ini merupakan kegiatan pengajian yang digagas oleh SBY ketika menjelang menunaikan haji pada tahun 2000. Pada waktu pertama kali berdiri, susunan pengurus yayasan ini adalah sebagai berikut: Ketua Dewan Pembina: H. Susilo Bambang Yudhoyono; Dewan Pembina: Hatta Rajasa, Sudi Silalahi, dan M. Maftuh Basyuni SH; Dewan Pengawas: Drs. H. Kurdi Mustofa MM, Habib Abdul Rahman M. al-Habsyi; Ketua Umum: H. Harris Thahir; Sekretaris: H. Edhie Baskoro Yudhoyono, dan H.M. Utun Tarunadjaja; Bendahara: H. Aziz Mochdar, H. Hartanto Edhie Wibowo; Kepala Sekretariat: H.M. Utun Tarunadjaja; Imam Dzikir: Habib Abdul Rahman M. al-Habsyi, Habib 'Ali bin Abdul Rahman alHabsyi, Ustaz Usman Syarif Sangaji; Seksi Sosial: H. Yayat Priyatna, H. Muhammad Andi, Seksi Humas: H. Dedi Afriadi SE, Kompol Heri Guritno; Koordinator Umum: KH. Abdul Wahid, H Effen Rochendi, H. Abbas Hilmi, H. Ahmad Kosasih, Habib Ahmad al-Aidit; Pelaksana Harian Kepala Sekretariat: H.M. Utun Tarunadjaja; Staf Sekretariat: Heri Cahyadi, Achmad Rifai, Wawan Kusnanda. ${ }^{5}$

Nampak bahwa kepengurusan majelis dzikir ini tidak menggunakan manajemen tradisional sebagaimana lembaga pengajian di masyarakat, tetapi lebih mengarah kepada manajemen organisasi yang bersifat kegiatan politik massa, misalnya hal itu terlihat pada kepengurusan organisasinya yang hanya memiliki seksi pengurus bidang sosial dan hubungan masyarakat. Selebihnya pada kegiatan sekretariat yang melakukan optimalisasi bagi kedua bidang tersebut.

Dalam hal kegiatan, pada awalnya Majelis Dzikir SBY fokus pada kegiatan di dua masjid, yakni, di Masjid Baitul Rahman di komplek Istana Negara dan di

realitas sosial, sedangkan al-i'jāz adalah membuktikan bahwa ayat al-Qur'an sesuai dengan teori ilmu mutakhir, kemudian makna istikhrāj al-'ilmi adalah bahwa penafsiran ayat atau tema terkait dapat memberikan inspirasi atau melahirkan bagi munculnya teori sosial atau teori ilmiah terkait.

${ }^{5}$ Sumber dari hasil wawancara dengan pengurus Majelis Dzikir SBY pada bulan Desember 2011. 
Masjid Istiqomah Cikeas. Kegiatannya juga tidak jauh berbeda dengan majelismajelis dakwah yang lain. Kegiatan utama dari Majelis Dzikir SBY adalah yang bersifat keagamaan dan sosial. Jadi kegiatan majelis dzikir ini, selain dzikir dan istighāsha (doa bersama) setiap malam Jumat, juga memberikan santunan. "Ya, itu dananya dari kita untuk mereka yang tidak mampu. Juga untuk bantuan bencana, kita mengajak jama'ah untuk menyalurkan infak dan sodaqoh", demikian menurut Wakil Sekretaris Umum dan Kepala Sekretariat Majelis Dzikir SBY, H.M. Utun Tarunadjaya. ${ }^{6}$

Menurut H. Hasan, sebagai salah-satu pengurus Majelis Dzikir SBY menyatakan bahwa "Dzikir dan doa ini semata kita lakukan sebagai salah satu bentuk untuk mendoakan bangsa ini maupun Bapak SBY. Selain itu pula, dengan kita mengangkat tema jadikan akhlakul karimah sebagai benteng demokrasi, bahwa dewasa ini proses demokrasi yang ada pada bangsa kita sudah tidak lagi menjujung asas demokrasi yang baik yang di landasi dengan etika dan moral", katanya saat acara dzikir dan doa bersama beberapa waktu lalu, setelah tersebarnya buku karya George Aditjondro yang mengungkap penggunaan uang Negara dalam kegiatan Majelis Dzikir SBY ini. Menurut H. Hasan, ketika menjawab tuduhan Aditjondro dengan menyatakan bahwa "Presiden SBY sadar kebebasan berpendapat di muka umum dijamin dalam Deklarasi Universal Hak Asasi Manusia (DUHAM) Pasal 19 yang isinya setiap orang berhak atas kebebasan berpendapat dan menyatakan pendapat. Seakan demokrasi itu dapat diartikan sebagai kebebasan dalam mencaci, memaki dan yang terburuknya hingga membantai siapa pun. Perlu kila sadari dalam membangun bangsa ini memang kita perlu demokrasi namun demokrasi yang dilandasi dengan etika dan moral". Nampak bahwa para pengurus Majelis Dzikir SBY, menguasai tidak hanya bidang spiritual tetapi juga hal-hal yang berkaitan dengan sistem dan aturan demokrasi, termasuk dari aspek hukum internasional.

Kegiatan utama majelis dzikir SBY "Nurussalam", pada mulanya adalah membaca surat Yāsīn dan Rātiban untuk mendoakan Letnan Jenderal Susilo Bambang Yudhoyono yang sedang melaksanakan ibadah haji tahun 2000 ke tanah suci Makkah dan Madinah agar ia diberi kemudahan dalam melaksanakan ibadah dan mendapat haji yang mabrur. Kemudian ketika menjelang Pemilihan

6Wawancara dengan pengurus Majelis Dzikir SBY pada bulan Desember 2011.

7Wawancara dengan pengurus Majelis Dzikir SBY pada bulan Desember 2011. 
Presiden 2004, kegiatan dzikir rutin dilaksanakan untuk mendoakan sang jenderal menuju kesuksesan dalam Pilpres dimaksud. Setelah terpilih dalam pemilihan Presiden, maka kemudian pada tahun 2005, Presiden Susilo Bambang Yudhoyono memerintahkan agar majelis dzikir membentuk yayasan, yang kemudian pada tanggal 5 Maret 2005 terbentuklah Yayasan Majelis Dzikir SBY "Nurussalam". Kegiatan ini menurut penuturan kepala sekretariat yayasan tersebut, H.M. Utun Tarunajaya, bertujuan menuju kebersamaan, memperkokoh persaudaraan Islam (ukhuwwah islämiyyah), mengajak umat untuk saling bahu membahu, saling asah-asih-asuh dalam rangka menegakkan kalimatillāh. Nampak dari tujuan tersebut menunjukkan kepada penggalangan masa dan meningkatkan image SBY dari aspek spritualitas.

Di samping secara rutin mengadakan kegiatan dzikir sekitar tiga (3) kali sebulan di Masjid Baiturrahman, Istana Presiden RI, Majelis Dzikir SBY juga melakukan kegiatan tahunan, seperti pembagian sembako menjelang masuknya bulan suci Ramadhan, pembagian sembako menjelang Idul Fitri, pemotongan hewan kurban Idul Adha, mengadakan sunatan massal saat liburan sekolah, dan santunan anakyatim menjelang perayaan 10 Muharam.

Kegiatan-kegiatan sosial tersebut tentu saja memberikan dampak positif bagi masyarakat terhadap rasa empati dan simpati mereka kepada sang Presiden. Sehingga ada ikatan emosional yang kuat melalui kegiatan spiritual dan sosial tersebut. Perkembangan selanjutnya, Majelis Dzikir SBY "Nurussalam" ini membentuk perwakilan di setiap propinsi. Bahkan dibentuk juga "Majelis Dzikir AnNisa Nurussalam" untuk kaum ibu, dan dibentuk juga "Himpunan Seni Budaya Islam" (HISBI) yang mengkoordinir kegiatan budaya klasik yang telah berkembang di berbagai masjid dan majlis taklim atau pesantren. Sebuah ekspos kegiatan keislaman yang cukup menggembirakan karena mampu menarik massa dari kalangan "santri" dan masyarakat Muslim perkotaan.

\section{Majelis Dzikir SBY “Nurussalam” sebagai Kelompok Kepentingan (Interest Group) di Era Reformasi}

Istilah interest group atau kelompok kepentingan, pada awalnya merupakan sebuah istilah baru dalam khazanah kehidupan masyarakat Indonesia, yang dalam kehidupan politik masyarakat Indonesia, istilah ini dapat dipahami dengan organisasi massa atau ormas. Bagi masyarakat Indonesia modern, istilah ini dapat juga dipahami sebagai Lembaga Swadaya Masyarakat (LSM) atau NonGovernment Organization (NGO). 
Dari aspek kegiatan publik secara umum, yayasan Majelis Dzikir SBY “Nurussalam" termasuk organisasi yang dikategorikan kepada "Kelompok Kepentingan" ini. Dalam dunia ormas non partisan, kelompok kepentingan (interest groups) dapat dimaknai sebagai sekumpulan orang yang memiliki kesamaan sifat, sikap, pemahaman, dan tujuan tertentu yang sepakat mengorganisasikan diri untuk melindungi dan mencapai tujuan organisasinya. Menurut Miriam Budiardjo, kelompok kepentingan (interest groups) bertujuan untuk memperjuangkan sesuatu 'kepentingan' dan mempengaruhi lembaga-lembaga politik seperti parpol agar mendapatkan keputusan yang menguntungkan atau menghindarkan keputusan yang merugikan. Kelompok ini lebih banyak memperjuangkan kepentingan umum. ${ }^{8}$

Tetapi di sisi lain, yayasan Majelis Dzikir SBY "Nurussalam”, tidak dapat dipungkiri, mengandung muatan politis dan merupakan lembaga think-tank politik kandidat SBY, sebagai capres pada pemilu 2004 dan 2009. Karena itu, sesuatu yang wajar, jika mengkategorisasikan lembaga ini sebagai bagian dari tim kampanye Capres dimaksud, atau sebagai lembaga politik.

Di sub ini, akan dibahas terlebih dahulu tentang hakikat kelompok kepentingan (interest groups), secara sekilas. Pemahaman tentang hakikat kelompok kepentingan, dapat menggunakan pendekatan gabungan makna dimaksud, baik secara ontologis, epistemologis dan aksiologis.

Sebuah organisasi kelompok kepentingan, di era reformasi ini, dalam berinteraksi dengan pemegang kebijakan atau pemerintah biasanya menggunakan pendekatan persuasif melalui lobi dan jaringan kerja yang intensif. Kemudian bila hal itu, tidak terjalin dengan baik, mereka dengan adagium "kekuatan HAM dan kebebasan mengeluarkan pendapat" bisa saja menggunakan cara-cara lain, untuk dapat menekan pihak dimaksud, misalnya melalui penggalangan massa untuk menolak kebijakan pemerintah yang dinilai tidak memihak kepada kepentingan publik. Dalam kondisi ini, mereka melakukan penyesuaian perjuangan mereka menjadi kelompok penekan (pressure group).

Tetapi untuk kasus Majelis Dzikir SBY "Nurussalam" di era kepemimpinan SBY atau partai demokrat tentu tidak akan menjadi "kelompok penekan", karena memang beberapa pengurus inti dari majelis dzikir ini menjadi bagian dalam pemerintahan SBY. Maka pemposisian majelis dzikir ini, dalam pemerintahan

8Miriam Budiardjo, Dasar-dasar Ilmu Politik, (Jakarta: Gramedia Pustaka Utama, 2004), h. 162. 
SBY tetap dalam berada kelompok kepentingan (interest groups). Karena itu, untuk mengetahui secara umum tentang hakikat kelompok kepentingan, ada beberapa klasifikasi terkait dengan kegiatan "kelompok kepentingan".

Berdasarkan klasifikasi "kelompok kepentingan" dari Almound, ${ }^{9}$ maka Majelis Dzikir SBY “Nurussalam” terklasifikasikan ke dalam kelompok keagamaan, yang memiliki ruang lingkup keanggotaan yang luas, dan di sisi lain termasuk kelompok institusional, karena menjadi bagian dari lembaga politik dari partai tertentu.

Berdasarkan tujuannya, Majelis Dzikir SBY "Nurussalam", sebagaimana telah dikemukakan, yaitu bertujuan menuju kebersamaan, memperkokoh persaudaraan Islam (ukhuwwah islāmiyyah), mengajak umat untuk saling bahu membahu, saling asah-asih-asuh dalam rangka menegakkan kalimatillāh. Sedangkan secara epistemologis, majlis dzkir ini melakukan kegiatannya dengan metode dzikir dan penggalangan massa. ${ }^{10}$

Dengan memperhatikan karakteristik, tujuan dan proses pelaksanaan kegiatan "Majelis Dzikir SBY "Nurussalam"'” nampak bahwa ada beberapa kata kunci yang dapat dijadikan landasan pemilahan ayat al-Qur'an terkait penafsiran tafsir ayat sosial integratif, yaitu ayat al-Qur'an yang berkaitan dengan konsep alummah, al-ukhuwwah al-islämiyyah dan al-ta'āwun.

\section{Majelis Dzikir SBY “Nurussalam” sebagai Bagian dari Tim Sukses Kampanye Presiden SBY di Era Reformasi}

Proses kampanye pemilu dengan kampanye politik, merupakan dua kegiatan yang saling melengkapi dan jika hanya dilakukan salah-satunya saja, akan berakibat kepada kurang efektifnya kegiatan dimaksud bagi pemenangan seorang kandidat atau partai politik dimaksud. Karena itu pula, Susilo Bambang Yudhoyono, sejak jauh-jauh hari telah mulai melakukan kegiatan kampanye politik, di antaranya melalui Majelis Dzikir SBY "Nurussalam" ini. Bahkan semenjak tahun 2000, secara informal kegiatan yang kemudian majelis dzikir ini telah dilakukan, yang kemudian di tahun 2005 diresmikan menjadi sebuah lembaga formal institusional sebagai bagian dari lembaga politik di bawah naungan pendirinya sendiri.

\footnotetext{
${ }^{9}$ Gabriel A. Almound Comparative Politic, dalam Mohtar Mas'oed, Perbandingan Sistem Politik, (Yogyakarta: Gajah Mada University Press; 2006), h. 55.

10Wawancara dengan pengurus Majlis Dzikir SBY Nurussalam pada bulan Desember 2011.
} 
Dengan memperhatikan kondisi yang terkait dengan teori kampanye politik para ilmuwan politik, maka dapatlah diambil kesimpulan bahwa ayat-ayat alQur'an yang terkait dengan Majelis Dzikir "Nurussalam” sebagai lembaga politik, hendaknya memperhatikan ayat-ayat yang berkenaan dengan tema "komunikasi dan strategi" secara umum sebagai sebuah entitas dakwah yang mampu mempengaruhi audiens (mukhātab) untuk mengikuti apa yang disampaikan oleh komunikator politik.

\section{E. Tafsir Komparatif terhadap Istilah al-Qur'an Terkait Tema dalam Konteks Kegiatan Majelis Dzikir SBY “Nurussalam”}

Peneliti memilah metode komparatif, 11 — sebagai langkah kelima dari metode Tafsir Ayat Sosial Integratif (TASIF) ini-12 merupakan satu cara untuk mengetahui pendapat para mufassir al-Qur'an dari Indonesia berkenaan dengan tema dimaksud. Penukilan pendapat dari pakar tafsir al-Qur'an yang diupayakan dari tokoh penulis Indonesia, agar konteks keindonesiaan, tetap bisa diperoleh terkait istilah-istilah atau konsep tersebut. Di sini penulis mengemukakan berbagai pendapat makna istilah dimaksud terkait tema tema "relasi politik dan dakwah". Selanjutnya penentuan istilah terkait tema dan konteks kegiatan Majelis Dzikir SBY "Nurussalam" dapat berkaitan dengan konsep al-ummah, alukhuwwah al-islāmiyyah, al-ta'āwun dan komunikasi serta strategi sebagai sebuah entitas dakwah politik.

\section{Konsep al-Ummah dalam al-Qur'an}

Lafal al-ummah dalam kamus Bahasa Arab, bermakna negara, masyarakat, generasi. ${ }^{13}$ Lafal al-ummah ini juga seakar kata dengan al-imāmah yang memiliki makna memimpin jalan, memimpin seseorang, posisi memimpin, atau seseorang yang diutamakan (precedence). ${ }^{14}$ Adapun menurut M. Quraish Shihab — seorang

\footnotetext{
${ }^{11}$ Adapun metode komparatif (al-manhaj al-muwāzan; al-muqāran) yang telah dilakukan oleh para pakar tafsir al-Qur'an adalah bertujuan: Pertama, menyingkap realitas melalui tawaran berbagai ide atau dalil. Kedua, menyingkap tentang mufasir yang terpengaruh oleh perbedaan mazhab, dan menyingkap para mufasir yang mengungkap tentang berbagai ide atau mazhab tertentu yang berbeda. Lihat: Muhammad 'Ali Iyāz̄, al-Mufassirŭn; Hayātuhum wa Manhajuhum, (Teheran: Muassasat alṬibāàt wa'l-Nasyr Wizārat al-Thaqāfat al-irsyād al-islāmī, 1373 H), h. 51.

12Lihat: footnote nomor 4 tentang langkah-langkah dalam metode tafsir integratif.

${ }^{13}$ Hans Wehr, a Dictionary of Modern Written Arabic, (Ithaca, New York: Spoken Language Services Inc, , 1976) editor: J. Milton Cowan, h. 25.

${ }^{14}$ Hans Wehr, a Dictionary of Modern Written Arabic, h. 25-26.
} 
ahli tafsir al-Qur'an-, kata ummah terambil dari kata amma - yaummu yang berarti menuju, menumpu, dan meneladani. Lebih lanjut ia menyatakan kata ini dari akar kata yang sama, lahir antara lain kata umm yang berarti ibu dan imām yang maknanya 'pemimpin'; karena keduanya menjadi teladan, tumpuan pandangan, dan harapan anggota masyarakat. Dalam kata 'ummat' terselip makna-makna yang cukup dalam. Umat mengandung arti gerak dinamis, arah, waktu, jalan yang jelas, serta gaya dan cara hidup. Untuk menuju pada satu arah, harus jelas jalannya, serta harus bergerak maju dengan gaya dan cara tertentu, dan pada saat yang sama membutuhkan waktu untuk mencapainya. ${ }^{15}$ Lafal ummah dalam QS. an-Nahl [16]: 120-123 bermakna "pemimpin", sedangkan pada QS. al-Mukminun [23]: 52 bermakna "agama" sebagai faktor integral.

Dengan demikian, konsep ummat atau ummah sebagai sebuah konseptual dapat bermakna kelompok masyarakat yang memiliki sistem kepemimpinan tertentu sebagai tempat bertumpu dan aturan yang dinamis dalam perkembangan masyarakatnya dengan tujuan yang disepakati bersama sehingga mereka bisa bersatu. Karena begitu dinamisnya term yang berasal dari al-Qur'an ini, sebagai sebuah konsep unik dari Islam, maka istilah-istilah asing dapat saja kompatibel dengannya, misalnya terdapat istilah nation (negara), clan, suku, society (mujtamä'/masyarakat), qawm (kaum), shu'ub, qabïlah, jamā'ah, dan sebagainya. Walaupun masing-masing istilah tersebut, memiliki ciri khas makna tertentu, sesuai dengan perkembangan masyarakatnya.

Menurut Dawam Rahardjo, manakala membahas term ummah, bahwa istilah ini telah dianggap sebagai istilah kunci dalam khazanah para peneliti dari dunia Barat (Eropa dan USA) manakala mereka ingin mengetahui tentang konsep politik dalam Islam.16 Dalam QS. al-A'raf [7]: 34 dikemukakan bahwa setiap ummat memiliki batas waktu (ajal), maka ia bisa ber-revolusi, ber-evolusi, bermodifikasi, atau bahkan hancur diganti oleh umat atau generasi yang lain. Oleh karena itu, di ayat selanjutnya. ${ }^{17}$ Tuhan menganjurkan agar "umat" atau kelompok masyarakat ini melakukan "perbaikan" (iṣlāh) dan "taqwā" (menjaga diri dalam nilai-nilai moral dan etika untuk memperoleh petunjuk Tuhan dan

\footnotetext{
15M. Quraish Shihab, Wawasan al-Qur'an: Tafsir Maudhu'i atas Pelbagai Persoalan Umat, (Bandung: Mizan, 2007), h. 325\&328

${ }^{16}$ Dawam Rahardjo, Ensiklopedi al-Qur'an: Tafsir Sosial Berdasarkan Konsep-konsep Kunci, (Jakarta: Paramadina, 2002), h. 482

${ }^{17} \mathrm{QS}$. al-A'raf [7]: 35 :
} 
kebenaran beragama), juga tidak takabur atau sombong dengan tidak membuat sistem yang mengarah kepada sikap tirani. Maka di sinilah pentingnya para Nabi - atau dalam konteks sekarang — para agamawan dan ilmuwan yang mampu memberikan bashīrā (reward) dan nadhïrā/punishment, ${ }^{18}$ sebagai sebuah sistem hukum. Tugas tersebut mendapat penguatan dari QS. Ali Imran [3]: 104 \& 110, yaitu adanya tugas bagi "kelompok elit" umat manusia untuk memerintahkan yang makruf (kebaikan kultural) dan mencegah atau melarang yang munkar (buruk; yang melanggar ajaran etika dan agama).

Ummat sebagai sebuah sistem politik dan kontrak sosial, telah dicontohkan oleh Nabi Muhammad SAW manakala ia bersama berbagai kelompok suku dan agama yang ada di Madinah membentuk sebuah kesepakatan atau perjanjian yang disebut dalam sejarah — sekitar $622 \mathrm{M}$ - dengan mithāq al-madīnah. Karakter perjanjian ini adalah moderat ${ }^{19}$, juga menjalankan nilai-nilai keberagamaan masing-masing kitab suci yang ditandai sikap tidak boros dan berparadigma kesejahteraan, sayangnya di antara mereka yakni sekelompok orang Yahudi dan beberapa kelompok suku melakukan hal-hal yang buruk. ${ }^{20}$

Menurut Munawir Sjadzali, prinsip dasar dalam Piagam Madinah sebagai landasan masyarakat majemuk sebagai ummat, adalah: a) semua pemeluk Islam meskipun berasal dari banyak suku, tetapi merupakan satu komunitas (ummat wāhidah); dan b) hubungan antara sesama anggota komunitas Islam dengan anggota komunitas non Islam didasarkan kepada prinsip: bertetangga yang baik, saling membantu dalam menghadapi musuh bersama, membela mereka (anggota kelompok yang teraniaya), saling menasihati, dan menghormati kebebasan beragama. ${ }^{21}$ Menurut Deddy Ismatullah — Rektor UIN Bandung periode 20112015-, Nabi Muhammad sebagai pemimpin ummat dalam perjanjian tersebut, menjalankan hablum min Allāh dan hablum min 'n-nās sekaligus, juga menggunakan prinsip musyawarah (al-shürā), ${ }^{22}$ sebagaimana yang diperintahkan dalam alQư'an di antaranya QS. al-Syura [42]: 38, Ali Imran [3]: 159, al-Naml [27]: 32.23

\footnotetext{
${ }^{18}$ QS. Fathir [35]: 24.

${ }^{19} \mathrm{QS}$. al-Baqarah [2]:142.

${ }^{20}$ QS. al-Ma'idah [5]: 66.

${ }^{21}$ Lihat: Munawir Sjadzali, Islam dan Tata Negara: Ajaran, Sejarah, dan Pemikiran, Oakarta: UI Press, 1993), h. 15-16.

${ }^{22}$ Lihat: Deddy Ismatullah dan Asep AS. Gatara, Ilmu Negara dalam Multi Perspektif: Kekuasaan, Masyarakat, Hukum, dan Agama, (Bandung: Pustaka Setia, 2007), h. 207.

${ }^{23}$ QS. al-Syura [42]: 38, Ali Imran [3]: 159, al-Naml [27]: 32.
} 


\section{Konsep al-Ukhuwwah al-Islämiyyah}

Ukhuwwah berasal dari kata al-akh yang bermakna persaudaraan atau persahabatan. ${ }^{24}$ Menurut M. Quraish Shihab, ukhuwwah pada mulanya berarti "persamaan dan keserasian dalam banyak hal", dan al-ukhuwwah al-islāmiyyah dapat bermakna "persaudaraan antar sesama kaum Muslim", atau "persaudaraan secara Islam, persaudaraan yang bersifat islami", 25 juga bermakna "persaudaraan dalam Islam". Berdasarkan pemahaman tentang teks al-Qur'an, persaudaraan dalam Islam, tidak melulu didasarkan atas landasan agama semata, tetapi karena faktor-faktor lainnya seperti persaudaraan karena anak angkat, karena adanya pembebasan, ${ }^{26}$ karena sesama umat manusia, ${ }^{27}$ karena samasama satu bangsa atau suku, ${ }^{28}$ karena memiliki sifat atau pola hidup yang sama, ${ }^{29}$ karena adanya hubungan perkawinan, ${ }^{30}$ dan karena kesamaan lainnya. Walaupun persaudaraan karena landasan agama ${ }^{31}$ dan sikap ihsān $n^{32}$ akan menjadi lebih kuat ikatan persaudaraannya. ${ }^{33}$

Di samping itu, persaudaraan dalam Islam, mengharuskan adanya sikap ișlāh ${ }^{34}$, tidak saling menjelekan, tidak berburuk sangka, serta saling berusaha untuk ta'āruf atau saling mengenal. ${ }^{35}$ Dengan kata lain, bahwa persaudaraan dalam Islam, akan terjalin dengan baik, jika syarat-syarat atau faktor tersebut diaplikasikan secara konsekuen dan didasari atas nilai-nilai etika agama.

Kuntowijoyo menafsirkan ayat ta'âruf ini $^{36}$ dengan objektivisme teosentris, resiprositas dan komunikasi dialogis egaliter. Menurutnya objektivisme teosentris merupakan paradigma dalam filsafat sosial Islam, termasuk hukum, etika,

\footnotetext{
${ }^{24}$ Hans Wehr, A Dictionary of Modern Written Arabic, h. 9.

25Lihat: M.Quraish Shihab, Membumikan al-Qur'an: Fungsi dan Peran Wahyu dalam Kehidupan Masyarakat, (Bandung: Mizan, 1995), h.357-358.

${ }^{26}$ QS. al-Ahzab [33]: 5.

${ }^{27} \mathrm{QS}$. al-Hujurat [49]: 12.

${ }^{28}$ QS. al-A'raf [7]: 7, Hud [11]: 11, al-'Ankabut [29]: 29.

${ }^{29}$ QS. al-Isra' [17: 27.

${ }^{30} \mathrm{QS}$. al-Baqarah [2]: 220.

${ }^{31}$ QS. al-Baqarah [2]: 256; al-Taubah [9]: 11.

${ }^{32}$ Sikap ihsān adalah berbuat baik melebih dari yang seharusnya dilakukan dan dilandasi dengan rasa ikhlas karena Allah serta tanpa pamrih.

${ }^{33}$ QS. Luqman [31]: 22.

${ }^{34} \mathrm{QS}$. al-Hujurat [49]: 10.

${ }^{35}$ QS. al-Hujurat [49]: 11-13.

${ }^{36}$ QS. al-Hujurat [49]: 13.
} 
ekonomi dan politik. Dalam paradigma ini, manusia harus memahami realitas secara objektif yang dilandasi atas nilai-nilai ketuhanan. Penyebutan realitas manusia yang terdiri atas beraneka bangsa dan suku serta pentingnya kemuliaan taqwa dalam kehidupan manusia pada ayat tersebut, menunjukan pentingnya paradigma objektivisme teosentris ini. Kemudian istilah "resiprositas" adalah hubungan timbal balik antar manusia dengan memahami kepentinga masingmasing baik secara horizontal maupun vertikal. Sedangkan dalam "komunikasi dialogis egaliter" mensyaratkan adanya sebuah Negara hukum, yang dapat menjamin terlaksananya kesamaan hak dan kewajiban setiap warga negara. ${ }^{37}$

\section{Konsep al-Ta'āwun}

Perintah untuk melakukan tolong-menolong disebutkan misalnya dalam QS. al-Ma'idah [5]: 2. Perintah pada ayat tersebut adalah menolong kepada siapa pun dalam bidang apapun yang bernilai positif, untuk kemaslahatan pihak yang ditolong dan untuk peningkatan kualitas takwa, baik sang penolong ataupun yang ditolong. Karena itu, kemaslahatan di sini bersifat kolektif, tidak elitis. Kemaslahatan yang lebih menguntungkan masyarakat dari pada kaum penguasa.

Menurut Kuntowijoyo, ta'âwun atau kerjasama dalam konteks nasional adalah penting didahulukan, sebelum diberlakukannya perdagangan bebas mulai 2020. Kerjasama nasional hanya dapat berjalan jika kita dapat menghilangkan dualisme ekonomi, monopoli, oligopoli, nepotisme, dan ersatz capitalism serta mempunyai pemerintahan yang bersih (tanpa korupsi dan kolusi). Istilah ta'āwun dalam Islam, mengandung dua sisi: kepentingan manusia dan "kepentingan" Tuhan. $^{38}$ Kepentingan Tuhan adalah terlaksananya sistem tatanan hidup universal, seperti konsep keadilan, dan pemberdayaan ekonomi kaum lemah, dan sebagainya.

Lafal yang digunakan dalam ayat tersebut adalah hendaknya menolong tentang hal-hal yang mengandung al-birr dan al-taqwā. Makna al-birr adalah kebajikan universal, sedangkan makna al-taqwā. Jika mencoba menyimpulkan dari berbagai penafsiran Dawam Rahardjo adalah kemampuan menjaga diri dalam nilai-nilai moral dan etika untuk memperoleh petunjuk Tuhan dan kebenaran beragama. ${ }^{39}$

\footnotetext{
${ }^{37}$ Lihat: Kuntowijoyo, Identitas Politik Umat Islam, (Bandung: Mizan, 1997), h. 92-94.

${ }^{38}$ Lihat: Kuntowijoyo, Identitas Politik Umat Islam, h. 98-99.

${ }^{39}$ Dawam Rahardjo, Ensiklopedi al-Qur'an..., pada tema “taqwa”.
} 
Pentingnya melakukan kebajikan (al-birr) juga dinyatakan dalam QS. Ali Imran [3]: 92. Sering kali kita memberi sesuatu yang "bekas" atau kita sendiri merasa sudah tidak lagi membutuhkannya, dengan alasan agar dari pada tidak mubazir. Padahal adanya penekanan dalam ayat tersebut bahwa kita baru bisa disebut sebagai "orang baik" dalam pandangan agama manakala materi yang kita berikan hendaknya merupakan sesuatu yang memang kita sendiri mencintainya atau menghendakinya, sehingga "sesuatu" yang diberikan itu betul-betul memiliki kualitas terbaik.

Kemudian di ayat lain yaitu QS. al-Taubah [9]: 53, 54, 121, mensyaratkan bahwa pemberian siapapun dan sekualitas apapun barang yang diberikan, jika diiringi dengan sifat "fasik" dan "pengingkaran" terhadap hukum-hukum Tuhan, maka pemberiannya tidak dipandang sebagai sebuah kebaikan yang hakiki atau kebaikan yang ia lakukan tersebut, tidak akan sampai kepada Tuhan dan tidak diterima sebagai sebuah nilai kebajikan.

Sifat "fasik" dan "pengingkaran" yang menjadi penghalang diterima suatu kebajikan dalam pandangan agama. Karakter atau sifat "fasik" merupakan sifat orang yang — suka atau terpaksa — sering melakukan perbuatan dosa, baik dosa ritual, sosial, maupun dosa dengan melakukan pengrusakan lingkungan (environment). 40 Berdasarkan penelitian Cawidu, bahwa term "fasik" menurut aliranaliran teologi dalam Islam merupakan prediket tambahan yang diberikan kepada orang mukmin pelaku dosa besar, baik ia tetap dianggap mukmin dengan perbuatannya itu, maupun sudah dikategorikan sebagai orang yang ingkar teologis $(k \bar{a} f i r) .{ }^{41}$ Tetapi di dalam al-Qur'an, perbuatan yang ditunjuk sebagai fasik, ada yang tergolong dosa besar dan ada yang tidak, ${ }^{42}$ namun harus diakui bahwa pada umumnya kefasikan yang disebut dalam al-Qur'an merujuk kepada dosa-dosa besar. Kalaupun tidak menunjukkan dosa besar secara eksplisit, namun perbuatan-perbuatan yang ditunjuk dengan term fasik ini umumnya menimbulkan dampak negatif yang cukup besar, khususnya terhadap kemaslahatan agama dan masyarakat. ${ }^{43}$

\footnotetext{
${ }^{40}$ Ayat yang menunjukan bahwa orang yang melakukan pengrusakan lingkungan adalah termasuk orang fasik, misalnya dalam QS. al-Baqarah [2]: 26-27.

${ }^{41}$ Harifuddin Cawidu, “Konsep Kufr dalam al-Qur'an”, Disertasi, (Jakarta: IAIN Jakarta; 1989), h. 80.

${ }^{42}$ Harifuddin Cawidu, “Konsep Kufr dalam al-Qur'an”, h. 81

${ }^{43}$ Harifuddin Cawidu, “Konsep Kufr dalam al-Qur'an”, h. 83.
} 


\section{Konsep Komunikasi sebagai Entitas Dakwah Politik dalam Perspektif al-Qur'an}

Relasi komunikasi dengan politik dalam istilah "komunikasi politik", sebagaimana dijelaskan di muka adalah yang pertama menjadi ujung tombak bagi yang kedua. Artinya komunikasi dapat dilakukan dengan tujuan politik. Komunikasi berada di depan sedangkan politik, merupakan sesuatu yang melatarbelakangi dilakukannya suatu komunikasi. Sedangkan komunikasi dan dakwah merupakan hubungan umum dan khusus, artinya komunikasi lebih umum dari pada dakwah, karena dakwah merupakan bahagian dari komunikasi yakni kedudukan dakwah lebih cenderung kepada komunikasi massa dari keilmuan komunikasi. Adapun dakwah politik merupakan ajakan untuk tujuan politik, sedangkan politik dakwah merupakan strategi dalam melaksanakan dakwah Islam. Maka komunikasi sebagai dakwah politik merupakan cara komunikasi untuk tujuan politik tertentu.

\section{F. Tafsir al-Qur'an tentang Komunikasi}

Ungkapan al-Qur'an yang menunjukan ada kaitan langsung dengan komunikasi dan dakwah, secara makna adalah ayat-ayat yang menyebutkan adanya perintah nasihat, menyampaikan dan mengajak kepada nilai-nilai ajaran agama (amar ma'rüf nahi munkar), memberi kabar gembira atau peringatan, perintah mengatakan atau menyatakan kepada orang lain, walaupun khitab atau audiens dari ayat adalah Rasul atau Nabi, tetapi dapat menunjukan juga perintah kepada umatnya. Secara lafal, ayat tentang komunikasi dan dakwah adalah ayat-ayat yang menggunakan derivasi dari kata-kata: al-da'wah, al-tablïgh, amar ma'rūf nahī munkar, al-qawl, al-nașịhah. Ayat-ayat dimaksud, di antaranya QS. alBaqarah [2]: 119, 221, 256, 257; al-Nahl [16]: 125; al-Qashash [28]: 56; al-Fath [48]: 29; al-Ma'idah [5]: 19, 54; Ali Imran [3]: 64, 104, 110, 159, 187; al-An'am [6]: 151-153; Ibrahim [14]: 10; al-Hajj [22]: 49-50; Yunus [10]: 25; al-A'raf [7]: 79, 85, 199; al-Balad [90]: 17; al-Shaff [61]: 2-3; al-Kahfi [18]: 29, 54, 56; al-Taubah [9]: 122; al-Isra' [17]: 53; al-Syu'ara' [26]: 214; al-Anbiya' [21]: 107; al-Ahzab [33]: 7071; al-Nisa' [4]: 63; al-'Ankabut [29]: 46; Thaha [20]: 43-44; al-'Ashr [103]: 1-3.

Dakwah sebagai komunikasi massa, sejalan dengan komunikasi politik yang lebih cenderung memanfaatkan komunikasi sebagai cara masif untuk menggalang massa. Dalam melakukan dakwah, dapat menggunakan berbagai metode, di antaranya: 1) Dakwah dengan metode ceramah (lisān al-maqāa); 2) Dakwah 
dengan metode keteladanan (uswah ḥasanah atau bi 'l-hāl); 3) Dakwah dengan metode cerita dan kesejarahan (al-qisssah); 4) Dakwah dengan metode wasiat (wașaya); 5) Dakwah dengan metode dialogis (al-hiwār); 6) Dakwah dengan metode musyawarah mufakat (al-shūrā baina rijāl al-mujtamā' atau muktamar organisasi); 7) Dakwah dengan metode dzikir dan spritualitas (al-dhikr wa tazkiyyat al-qalb).

Adapun ketujuh metode tersebut, hendaknya bermuatan tiga hal: hikmah, nasihat, dan argumentatif, sebagaimana disebutkan dalam QS. al-Nahl [16]: 125. Hikmah adalah ilmu yang dapat menggerakan masyarakat atau individu kepada kemanfaatan atau kemaslahatan sesuai dengan konteks perkembangan zaman dan kondisi yang tepat. Istilah "Nasihat" yang berasal dari bahasa Arab ini, secara leksikal bermakna kemurnian (khalașa), merajut atau menjahit (khäța). Maka nasihat dapat dimaknai dengan kemampuan mengkolaborasikan berbagai potensi yang dimiliki sehingga sesuai dengan kondisi dan apa yang dikehendaki oleh sang pemesan, sebagaimana penjahit mampu menyatukan berbagai kain, sehingga membentuk mode suatu pakaian yang diinginkan oleh sang pemesannya tanpa memasukan keinginan pribadi sang penjahit.

Adapun makna argumentatif adalah argumentasi dengan menggunakan berbagai perumpamaan (al-mathal) dan analogi dengan cara yang ihsān sehingga dapat diterima dengan lapang dada. Istilah "ihsān" dapat dimaknai dengan "kebaikan yang mengandung kebajikan bagi komunikan atau mukhätab." Adapun penjelasan ringkas terhadap masing-masing metode tersebut yaitu, sebagai berikut:

Pertama, dakwah dengan metode ceramah (lisān al-maqāl). Seorang da'i atau penceramah, hendaknya memiliki kemampuan dalam menggunakan diksi kalimat atau kata-kata sehingga dapat mudah dipahami oleh lawan bicaranya atau mukhātab (audiens). Terdapat beberapa istilah, dalam al-Qur'an yang menunjukkan tentang kemampuan ini, yaitu:

a. QS. al-Ahzab [33]: 70-71 mengungkap istilah qawlan sadīdā. Istilah ini dapat bermakna ucapan yang tepat sasaran (șawab) dan bernilai adanya perbaikan (qāim). Ucapan ini dapat bersifat persuasif dan keluar dari hati yang bersih, sekaligus memiliki kekuatan moral karena berasal dari orang yang memiliki kualitas taqwa terlebih dahulu. Menurut Achmad Mubarok, ungkapan yang persuasif memiliki kekuatan berikut: kekuatan keindahan bahasa; kekuatan intonasi suara yang berwibawa; kekuatan logika yang mendalam; kekuatan 
adanya optimisme/harapan (basyirran); kekuatan adanya peringatan yang mencekam (nadhiran); kekuatan ungkapan yang penuh ibarat/perumpamaan; ${ }^{44}$

b. QS. al-Nisa' [4]: 63 mengungkap istilah qawlan balīghā. Istilah ini secara kebahasaan adalah ucapan yang fasih dan sesuai dengan kondisi mukhātab (audiens). Karena itu dapat berarti "ungkapan yang berkualitas" atau dalam ilmu komunikasi merupakan "komunikasi yang efektif". Menurut Jalaluddin Rakhmat, pengertian qawlan balighā adalah komunikator menyesuaikan perkataannya dengan frame of reference dan field of experience, juga komunikator mampu menyentuh khalayak pada hati dan kalbu sekaligus;; ${ }^{45}$

c. QS. Thaha [20]: 43-44 mengungkap istilah qawlan layyinā, yang bermakna "ucapan yang lemah-lembut". Perkataan ini mengandung arti bahwa hendaknya dakwah disampaikan dengan kalimat yang menyejukan, sehingga tidak memacu emosi sang mukhātab apalagi jika yang diajak bicara adalah penguasa yang tiran dan tidak memiliki kedekatan psikologis, sebagaimana Fir'aun dalam kisah ayat tersebut;

d. QS. al-Baqarah [2]: 235, al-Nisa' [4]: 5 dan 8, al-Ahzab [33]: 32, keempat ayat tersebut menyebut istilah qawlan ma'rüfä. Lafal ma'rüf bermakna: kebaikan kultural, artinya sesuatu yang dianggap pantas oleh suatu kelompok atau masyarakat. Maka qawlan ma'rüfä bermakna "ucapan yang dianggap pantas atau wajar sesuai dengan adat-istiadat suatu masyarakat, atau komunikasi etis." Menurut Jalaluddin Rakhmat, dalam sebuah seminar, bahwa qawlan ma'rūfā adalah pembicaraan yang bermanfaat, memberikan pengetahuan, mencerahkan pemikiran, menunjukan pemecahan terhadap kesulitan kepada orang lemah, jika kita tidak dapat membantu secara material, kita harus dapat membantu psikologi; 46

e. QS. al-Isra' [17]: 23, mengungkap istilah qawlan karīmā. Maknanya adalah "ucapan yang mulia, santun, penuh hormat dan penghargaan, tidak menggurui, juga tidak menggunakan retorika yang meledak-ledak". Biasanya kondisi audiensnya adalah para orang tua yang kondisi fisiknya mulai melemah atau mudah tersinggung;

\footnotetext{
${ }^{44}$ Achmad Mubarok, Psikologi Dakwah, (Pustaka Firdaus; Jakarta, 2001), h. 183

45Jalaluddin Rakhmat, Islam Aktual, (Mizan; Bandung, 1996), h. 83.

${ }^{46}$ Jalaluddin Rakhmat, "Etika Komunikasi Perspektif Religi', Seminar di Perpusnas; Jakarta, pada tanggal 18 mei 1996.
} 
f. QS. al-Isra' [17]: 28 mengungkap istilah qawlan maysūrā. Istilah ini dapat bermakna "perkataan yang mudah dipahami, ringan, dan tidak berliku-liku". Biasanya digunakan kepada audiens yang tidak membutuhkan banyak penjelasan, karena tingkat intelektualnya sederhana dan baginya yang terpenting langsung ke inti yang diinginkannya, misalnya yang bersifat material.

Kedua, dakwah dengan metode keteladanan (uswah hasanah atau bi 'l-hāl); keteladanan dalam masyarakat Indonesia dikenal istilah tut wuri handayani dan teladan utama dalam Islam adalah Nabi Muhammad SAW. Ada empat karakter atau sifat para Nabi dalam memimpin umat: a) șiddiq (transparansi); b) amānah (kompetensi); c) tabligh (komunikatif); d) fațānah (intelegensi). Sedangkan dakwah dengan bi '-h-hăl menurut Yunan Yusuf adalah kegiatan dakwah melalui aksi atau tindakan nyata sehingga berorientasi kepada pengembangan masyarakat ${ }^{47}$ Terkait dengan uswah hasanah, seorang da'i hendaknya mengamalkan kode etik dakwah, di antaranya: a) Sesuai antara ucapan dengan perbuatan; b) Memegang teguh nilai-nilai tauhid atau memiliki keyakinan yang mantap; c) Tidak menghina Tuhan-Tuhan agama lain; d) Tidak melakukan diskriminasi sosial dalam berdakwah dan dalam keseharian; e) Tidak meminta imbalan dakwah atau memiliki niat ikhlas dalam berdakwah; f) Tidak berteman dengan pelaku maksiat; g) Tidak menyampaikan hal-hal yang belum diketahui dan selalu belajar. ${ }^{48}$

Ketiga, dakwah dengan metode cerita dan kesejarahan (al-qișsah). Dalam QS. Yusuf [12]: 111, dinyatakan bahwa kisah-kisah yang termuat dalam kitab suci dapat mengandung nilai-nilai penting untuk dijadikan pelajaran bagi manusia yang mau memikirkan kisah itu. Kisah yang terdapat dalam al-Qur'an juga dapat dijadikan pelajaran bagi para da'i untuk mengetahui metode para Nabi dalam berdakwah. Demikian juga menceritakan nilai-nilai positif dari sejarah masa lalu sebagai pelajaran penting untuk mengetahui contoh solusi yang pernah mereka aplikasikan dalam sejarah, termasuk memahami kekurangan yang ada.

Keempat, dakwah dengan metode wasiat (wașaya); ungkapan al-Qur'an yang menunjukan adanya perintah wasiat diantaranya terdapat dalam QS. al-Nisa' [4]: 131. Terdapat beberapa makna wasiat, di antaranya adalah "ucapan berupa

\footnotetext{
${ }^{47}$ Yunan Yusuf, "Dakwah bil Hal”, Jurnal Kajian Dakwah dan Kemasyarakatan, IAIN Syarif Hidayatullah, Jakarta, Vol. 3, No. 2. 2001.

48Syaikh Musthofa Mashur, Fikih Dakwah, (Jakarta: al-I'tisham Cahaya Umat, 2000), h. 98
} 
arahan atau pedoman kepada orang lain terhadap sesuatu yang belum dan akan terjadi". ${ }^{49}$ Sedangkan menurut M. Quraish Shihab, wasiat adalah: "ucapan yang bermuatan perintah tentang sesuatu yang bermanfaat dan mencakup kebaikan yang banyak". Kandungan wasiat dalam ayat tersebut adalah "taqwa" dan taqwa merupakan simpul kebajikan. ${ }^{50}$ Beberapa ayat lain, yang mengandung pesan bernilai wasiat adalah QS. al-Nisa' [4]: 151-153, di ayat tersebut terdapat sepuluh wasiat Allah swt yang terekam dan penting dilaksanakan umat manusia. Demikian juga pesan bernilai wasiat bisa didapat dalam QS. al-An'am [6]: 153, alBalad [90]: 17, dan al-'Ashr [103]: 3. Juga terdapat pesan wasiat Nabi kepada ulama, di antaranya perintah amar ma' 'rüf nahi munkar.

Kelima, Dakwah dengan metode dialogis (al-hiwār); ada beberapa etika dialog yang perlu diperhatikan, agar tujuan dari dialog tercapai dengan baik, yaitu: a) Adanya kejujuran kedua belah pihak; b) Adanya penentuan tema dialog dan objektif dalam mensikapi permasalahan, sehingga arah pembicaraan lebih jelas serta dapat tercapai sasaran yang diinginkan kedua belah pihak; c) Argumentative dan logis, sehingga masing-masing pihak menyadari dan memahami apa yang diinginkan kedua belah pihak dengan tanpa menggunakan otot; d) Bertujuan untuk mencapai kebenaran permasalahan dengan melihat berbagai perspektif; e) Tawadlu dalam mengemukakan pendapat dan alasan masing-masing; f) Memberi kesempatan kepada lawan bicara untuk mengemukakan alasan dengan tanpa menjelek-jelekan kepribadian, juga dalam menanggapi ide-ide dan pikiran yang dituangkan. ${ }^{51}$ Contoh ayat yang menunjukkan pentingnya adanya dialog dalam berdakwah, misalnya tersebut dalam QS.Alu Imran [3]: 64, al-'Ankabut [29]: 46, al-Kahfi [18]: 56, al-An'am [6]: 63-64, Yunus [10]: 15, dan al-Ghasiyah [88]: 17-20.

Keenam, dakwah dengan metode musyawarah untuk mencapai yang terbaik (al-shūrā baina rijāl al-mujtamā' atau muktamar organisasi), makna musyawarah pada mulanya bermakna "mengeluarkan madu dari sarang lebah". Dalam alQur'an, musyawarah dapat dilakukan untuk segala masalah yang belum terdapat petunjuk agama secara jelas dan pasti, sekaligus yang berkaitan dengan ke-

\footnotetext{
${ }^{49} \mathrm{Abu}$ Abdillah bin Furaihan, al-Ajwibah al-mufidah 'an al-as ïlah al-manāhij al-jadīdah, (Surakarta: Yayasan Madinah, 1997), (terjemahan), h. 31.

50Lihat: M. Quraish Shihab, Tafsir al-Mishbah, (Jakarta: Lentera Hati, 2000), jilid 2, h. 584.

51Sayyid Muhammad Tanthawi, Adab al-Hiwār fi I-Islām, (Dar al-Nahdah; Mesir), versi terjemahan, (Jakarta: Azan), h. 18
} 
hidupan duniawi. ${ }^{52}$ Musyawarah dalam Islam, dilakukan oleh orang-orang yang ahli di bidang tertentu. Artinya syarat untuk melakukan musyawarah adalah memiliki kompetensi (amānah) dan intelektualitas (al-ilm). Lebih lanjut menurut M. Quraish Shihab bahwa tidak mudah melibatkan seluruh anggota masyarakat dalam musyawarah itu, tetapi keterlibatan mereka dapat diwujudkan melalui orang-orang tertentu yang mewakili mereka, yang oleh para pakar diberi nama berbeda-beda sekali dengan ahl al-hăl wa al-'aqd, dikali lain dengan ahl al-ijtihād, dan kali ketiga ahl al-shūrā. Penamaan ahl al-shūrā merupakan istilah umum, yang kepada mereka para penguasa dapat meminta pertimbangan dan saran. Jika demikian tidak perlu ditetapkan secara rinci dan ketat sifat-sifat mereka, tergantung pada persoalan apa yang sedang dimusyawarahkan.

Sebagian pakar kontemporer memahami istilah ahl al-ḥāl wa 'aqd sebagai orang-orang yang mempunyai pengaruh di tengah masyarakat, sehingga kecenderungan mereka kepada satu pendapat atau keputusan mereka dapat mengantarkan masyarakat pada hal yang sama. Muhammad 'Abduh memahami ahl al-hāl wa al-'aqd sebagai orang yang menjadi rujukan masyarakat untuk kebutuhan dan kepentingan umum mereka, yang mencakup pemimpin formal maupun non-formal, sipil maupun militer. Adapun ahl al-ijtihäd adalah kelompok ahli dan para teknokrat dalam berbagai bidang dan disiplin ilmu. ${ }^{53}$

Musyawarah dalam Islam tidak hanya bersama orang yang seagama, tetapi dengan non agama, juga dianjurkan. Hal itu diisyaratkan dalam QS. Ali Imran [3]: 159, dan itu menunjukan bahwa Islam adalah rahmat bagi semua makhluk (raḥmatan li 'l-'âlamìn). Karena itu konsep Islam mesti mengikuti perkembangan zaman, dan dalam berbagai kondisi atau tempat. Maka relasi musyawarah dengan demokrasi yang mulai berkembang di era modern, adalah bahwa musyawarah dapat menjadi prinsip-prinsip utama bagi dilakukannya praktik demokrasi di era Negara bangsa. Demokrasi tanpa prinsip musyawarah akan melahirkan calon atau kandidat pemimpin yang tidak memiliki kapabilitas yang memadai, sebagaimana yang disyaratkan dalam al-shūrā.

Ketujuh, Dakwah dengan metode dzikir dan spritualitas (al-dhikr wa tazkiyyat al-qalb). Dzikir pada mulanya bermakna "mengingat" dan yang dimaksud di sini adalah "mengingat Tuhan agar dapat dekat dengan-Nya". Sebagaimana

\footnotetext{
52Lihat: M. Quraish Shihab, Wawasan al-Qur'an: Tafsir Maudhu'i atas Pelbagai Persoalan Umat, (Mizan; Bandung, 2007), tema musyawarah.

${ }^{53}$ M. Quraish Shihab, Wawasan al-Qur'an..., h. 481.
} 
riwayat Imam Muslim, Rasulullah SAW bersabda: "Tidak berkumpul suatu jama'ah dalam rangka berdzikir kepada Allah melainkan mereka akan dipelukoleh para malaikat, dilindungi atas mereka rahmat, dan turun ke atas mereka ketenangan dan mereka akan diingat oleh Allah SWT di hadapan sekalian makhluk yang ada pada sisi-Nya."

Praktek dzikir merupakan bagian dari kegiatan tasawuf. Dalam Islam dikenal istilah hakikat dan syariat. Hakikat adalah praktek tasawuf sedangkan syariat merupakan landasan hukum Islam. Secara definitif, "syariat" menurut Abu alQasim al-Qusyairi, adalah perkara atau ketentuan yang mengharuskan adanya ibadah, sedangkan "hakikat" adalah penyaksian ketuhanan. Ada yang menafsirkan bahwa "hakikat" adalah menyaksikan Tuhan melalui perantara hati, sedangkan "syariat" adalah mengetahui tata cara (al-suluk) menuju Tuhan. Relasi keduanya, saling melengkapi, karena "syariat" tanpa melaksanakan "hakikat" maka ibadahnya bisa tidak diterima, sedangkan setiap "hakikat" yang tidak diikat dengan "syariat" maka tidak akan berhasil. Dengan syariat, manusia menyembah Allah, dan dengan "hakikat", manusia dapat "menyaksikan" Allah. Bahkan penafsiran dalam QS. al-Fatihah: iyyāka na'budu bisa terpelihara dengan "syariat" dan iyyāka nastaîn merupakan ketetapan dengan hakikat.54 Maka dzikir merupakan cara untuk mendekati Allah, sekaligus menjauhi hawa nafsu.

Orang yang mengikuti hawa nafsunya berarti ia telah melupakan Allah SWT. Di dalam QS. al-Jatsiyah [45]: 23, disebutkan: "Maka pernahkah kamu melihat orang yang menjadikan hawa nafsunya sebagai tuhannya, dan Allah membiarkannya sesat berdasarkan ilmu-Nya dan Allah telah mengunci mati pendengaran dan hatinya dan meletakkan tutupan atas penglihatannya? Maka siapakah yang akan memberinya petunjuk sesudah Allah (membiarkannya sesat). Maka mengapa kamu tidak mengambil pelajaran?" Menurut berbagai pendapat, makna "Allah menyesatkan manusia" adalah "Allah menjauhkan manusia itu dari memperbaiki kualitas hatinya sehingga ia melupakan Tuhannya dan sibuk dengan kehidupan duniawinya, dan segala potensi yang ia miliki — baik pendengaran, penglihatan, bahkan potensi jiwanya - semuanya diarahkan kepada kehidupan duniawi karena terbawa oleh keinginan hawa nafsunya." Sehingga antitesa dari epistemologi dzikir kepada Allah SWT, adalah mengikuti hawa nafsu, sedangkan dzikir kepada Allah adalah cara untuk mengikis keinginan

\footnotetext{
${ }^{54}$ Lihat: Abu al-Qasim al-Qusyairi, al-Risālah al-Qushairiyyah fi Ilmi al-Tașawwuf, (ttp.: Dar al-Khair; t.th.), h. 82-83.
} 
hawa nafsu untuk memurnikan potensi hati manusia agar mampu berdekatdekat dengan Tuhan.

Menjalankan ibadah ritual, seperti shalat adalah satu cara untuk mengingat atau dzikir kepada Tuhan.55 Demikian juga dalam ibadah puasa, sebagaimana disebutkan dalam sebuah hadits yang cukup terkenal:

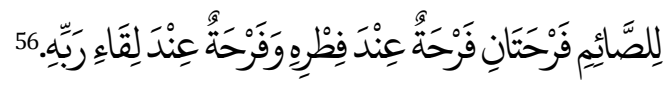

"Untuk orang yang berpuasa mempunyai dua kebahagiaan, yaitu kebahagiaan ketika berbuka dan kebahagiaan ketika melihat Tuhannya".

Bahkan menurut para peneliti Islam, bahwa semua aktivitas dalam ajaran Islam adalah bersifat teosentrisme, segala sesuatu bermula dan berakhir kepada Tuhan bagi terciptanya kebahagiaan manusia di dunia dan akherat sekaligus. Karena itu makna dzikir secara luas adalah tidak hanya menyebut nama Allah secara lisan, tetapi menyebutkan dalam hati, dan dalam hembusan napas. Termasuk semua aktivitas keseharian orang mukmin dapat menjadi aplikasi dari dzikir kepada Allah, sebagai sebuah ketundukan untuk menjalankan tugas utamanya yakni beribadah kepada sang penciptanya. Beribadah secara sosial pun termasuk dzikir kepada-Nya.

Dalam al-Qur'an, manusia diperintahkan berdzikir kepada Allah SWT agar ia mendapat limpahan rahmat-Nya, ${ }^{57}$ menghapus perbuatan dosa, ${ }^{58}$ agar tidak tergoda oleh rayuan maut setan, ${ }^{59}$ sebagai substansi dari kegiatan shalat, ${ }^{60}$ agar mampu mensucikan jiwanya dengan cara mensucikan Tuhan-nya, ${ }^{61}$ menghilangkan sifat lalai,62 dan tujuan lainnya yang dapat memberikan kemanfaatan individual atau kolektif manusia. ${ }^{63}$

Menurut penulis kitab al-Risālah al-Qushairiyyah, dzikir adalah pondasi yang kuat dalam menempuh jalan Tuhan (al-haqq), bahkan dzikir dapat menjadi

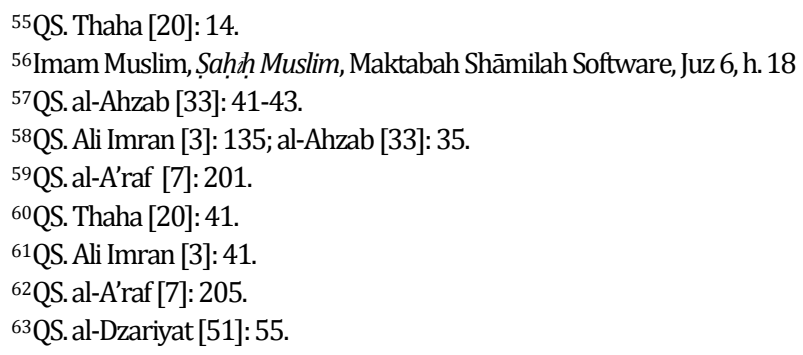


pondasi utamanya, dan tidak ada yang mampu sampai kepada Tuhan kecuali dengan dawam dalam berdzikir. Dzikir ada dua macam: dzikir lisan dan dzikir hati. Dzikir lisan dapat menyampaikan seorang hamba (manusia) kepada keberlangsungan dzikir hati dan berpengaruh kepada dzikir hati. Jika seorang hamba (manusia) itu berdzikir dengan lisan dan hatinya, maka sifat/karakternya sempurna dalam kondisi perjalanannya menuju Tuhan.64 Dalam perkembangan ilmu tasawuf, dzikir kepada Tuhan ada yang berdasarkan ajaran tarikat (alțarīqat)-nya masing-masing dan ada yang non-tarikat. Kelompok yang nontarikat biasanya melakukan dzikir dengan menggunakan al-asmä' al-ḥusnā dengan tanpa mengikuti aturan teknis dari tarikat, seperti aturan dari segi jumlah yang harus diucapkan, dan aturan lainnya yang dapat membantu sālik (penempuh jalan Tuhan) untuk mendekatkan dirinya kepada sang Khalik baik dari ahwāl ataupun maqūmāt.

Para pakar tasawuf, misalnya memberikan kategorisasi terhadap para penempuh jalan Tuhan tersebut, yaitu dengan beberapa tahap: pertama, meningkatkan ma'rifah melalui pengetahuan dan ketaqwaan; kedua, membebaskan diri dari perbudakan syahwat dan hawa nafsu; ketiga, menyucikan jiwa dengan jalan berakhlak dengan akhlak Allah SWT. ${ }^{65}$

\section{G. Kesimpulan}

Penafsiran ayat al-Qur'an terkait tema tentang relasi politik dan dakwah, dalam konteks kegiatan Majelis Dzikir SBY "Nurussalam", dapat dipilah sebuah sub tema penting yaitu: "Majelis Dzikir SBY "Nurussalam" sebagai Kelompok Kepentingan (Interest Group) di Era Reformasi." Dengan memperhatikan karakteristik, tujuan, dan proses pelaksanaan kegiatan Majelis Dzikir SBY "Nurussalam" nampak bahwa ada beberapa kata kunci yang dapat dijadikan landasan pemilahan ayat al-Qur'an berdasarkan sistematika penafsiran Tafsir ayat sosial integratif, yaitu ayat al-Qur'an yang berkaitan dengan konsep al-ummah, alukhuwwah al-islāmiyyah, dan al-ta'āwun, juga tema tentang "komunikasi, dan strategi" secara umum sebagai sebuah entitas dakwah.

\footnotetext{
${ }^{64}$ Lihat: Abu al-Qasim al-Qusyairi, al-Risālah al-Qushairiyyah...., h. 221.

${ }^{65}$ M. Quraish Shihab, Menyingkap Tabir Ilahi: al-Asma' al-Husna dalam Perspektifal-Qur'an, (Jakarta: Lentera Hati, 2006), h. xl.
} 
Dakwah sebagai komunikasi massa, sejalan dengan komunikasi politik yang lebih cenderung memanfaatkan komunikasi sebagai cara masif untuk menggalang massa. Sehingga dalam melakukan dakwah politik, dapat juga menggunakan berbagai metode dalam dakwah agama, di antaranya: 1) Dakwah dengan metode ceramah (lisān al-maqāl); 2) Dakwah dengan metode keteladanan (uswah hasanah atau bi 'l-hăl); 3) Dakwah dengan metode cerita dan kesejarahan (al-qișsah); 4) Dakwah dengan metode wasiat (wașaya); 5) Dakwah dengan metode dialogis (al-hiwār); (6) Dakwah dengan metode musyawarah mufakat (al-shūrā baina rijāl al-mujtamō' atau muktamar organisasi); 7) Dakwah dengan metode dzikir dan spritualitas (al-dhikr wa tazkiyyat al-qalb).

Kemudian makna al-ummah yang menjadi bagian dari konsep dakwah politik, bisa dimaknai sebagai "Negara bangsa". Keberlangsungan al-ummah sebagai negara ini adalah mensyaratkan di antaranya melakukan "perbaikan" (iṣlāh) dan "taqwā" (menjaga diri dalam nilai-nilai moral dan etika untuk memperoleh petunjuk Tuhan dan kebenaran beragama), juga tidak takabur atau sombong dengan tidak membuat sistem yang mengarah kepada sikap tirani.

Demikian juga makna al-ukhuwwah al-Islāmiyyah (persaudaraan dalam Islam), tidak melulu didasarkan atas landasan agama semata, tetapi karena faktor kesamaan lain yang bersifat non-agama.Walaupun persaudaraan karena landasan agama dan sikap ihsān akan menjadi lebih kuat nilai ikatan persaudaraannya. Juga mengharuskan adanya sikap ișlăh̆, tidak saling menjelekan, tidak berburuk sangka, serta saling berusaha untuk ta'āruf atau saling mengenal. Ta'āruf ini dapat bermakna objektivisme teosentris, resiprositas dan komunikasi dialogis egaliter.

Makna ta'āwun dalam Islam, mengandung dua sisi: kepentingan manusia dan "kepentingan" Tuhan. Kepentingan Tuhan adalah terlaksananya sistem tatanan hidup universal, seperti konsep keadilan, dan pemberdayaan ekonomi kaum lemah, dan sebagainya. Kepentingan manusia dalam konteks ini adalah terlaksana tujuan politik yakni kemenangan sang kandidat dalam kampanye politik.

Berbagai metode dalam dakwah agama tersebut, sekaligus menjadi sebuah entitas dalam metode dakwah politik. Tentu saja penggunaan metode tersebut dalam perspektif tafsir integratif merupakan sebuah upaya untuk memunculkan pengayaan dalam metode dakwah politik yang sebelumnya merupakan konsep dalam dakwah agama. Dengan demikian, tujuan istikhrāj al-ilm, sebagai tujuan dari metode tafsir integratif dapat saja diwujudkan dalam kegiatan kampanye 
politik. Yakni proses dialog teks al-Qur'an terkait politik dakwah dengan memanfaatkan konteks politik tertentu berdasarkan langkah-langkah tafsir integratif, mampu melahirkan suatu metode dalam kampanye politik, sebagaimana dimaksud.[w] 


\section{BIBLIOGRAFI}

Almound, Gabriel A., Comparative Politic, 1978, dalam Mohtar Mas'oed; Perbandingan Sistem Politik, Yogyakarta: Gajah Mada University Press, 2006.

Budiardjo, Miriam, Dasar-dasar Ilmu Politik, Jakarta: Gramedia Pustaka Utama, 2004.

Cawidu, Harifuddin, "Konsep Kufr dalam al-Qur'an", Disertasi, Jakarta: IAIN Jakarta, 1989.

Firmanzah, Marketing Politik antara Pemahaman dan Realitas, Jakarta: Yayasan Obor Indonesia, 2008.

Furaihan, Abu Abdillah, al-Ajwibah al-Mufidah 'an al-As ìlah al-Manāhij al-Jadīdah, Surakarta; Yayasan Madinah, 1997.

Hanafi, Hasan, Metode Tafsir dan Kemaslahatan Umat, Jogjakarta: Nawesea Press, 2007.

Ismatullah, Deddy dan Asep AS. Gatara, Ilmu Negara dalam Multi Perspektif: Kekuasaan, Masyarakat, Hukum, dan Agama, Bandung: Pustaka Setia, 2007.

Iyāzī, Muhammad 'Ali, al-Mufassirūn: Hayātuhum wa Manhajuhum, Teheran: Muassasat al-Ṭibā'at wa al-Nasyr Wizārat al-Thaqāfat al-Irsyād al-Islāmī, $1373 \mathrm{H}$.

Kahmad, Dadang, Sosiologi Agama, Bandung: Rosda Karya, 2006.

Kuntowijoyo, Identitas Politik Umat Islam, Mizan; Bandung, 1997.

Mashur, Syaikh Musthofa, Fikih Dakwah, Jakarta: al-I'tisham Cahaya Umat, 2000.

Mubarok, Achmad, Psikologi Dakwah, Pustaka Firdaus; Jakarta, 2001.

al-Qusyairi, Abu al-Qasim, al-Risālah al-Qushairiyyah fi 'Ilmi al-Tașawwuf, t.t.p: Dar al-Khair; t.th.

Rahardjo, Dawam, Ensiklopedi al-Qur'an: Tafsir Sosial Berdasarkan Konsep-konsep Kunci, Paramadina; Jakarta, 2002.

Rakhmat, Jalaluddin, "Etika Komunikasi Perspektif Religi", Seminar di Perpusnas; Jakarta, pada tanggal 18 Mei 1996.

Rakhmat, Jalaluddin, Islam Aktual, Mizan; Bandung, 1996.

Walisongo, Volume 22, Nomor 1, Mei 2014 
Shihab, M. Quraish, Membumikan al-Qur'an: Fungsi dan Peran Wahyu dalam Kehidupan Masyarakat, Bandung: Mizan, 1995.

Shihab, M. Quraish, Menyingkap Tabir Ilahi: al-Asma' al-Husna dalam PerspektifalQur'an, Jakarta: Lentera Hati, 2006.

Shihab, M. Quraish, Tafsir al-Misbah, Lentera hati; Jakarta, 2000.

Shihab, M. Quraish, Wawasan al-Qur'an: Tafsir Maudhu'i atas Pelbagai Persoalan Umat, Bandung: Mizan, 2007.

Sjadzali, Munawir, Islam dan Tata Negara: Ajaran, Sejarah dan Pemikiran, Jakarta: UI Press, 1993.

Tanthawi, Sayyid Muhammad, Adab al-Hiwār fi 'l-Islām, terj., Dar al-Nahdah; Mesir, Jakarta: Azan, t.th.

Varma, S.P., Teori Politik Modern, Jakarta: RajaGrafindo Persada, 2007.

Wehr, Hans, A Dictionary of Modern Written Arabic, Ithaca, New York: Spoken Language Services Inc, 1976.

Yusuf, Yunan, “Dakwah bil Hal," Jurnal Kajian Dakwah dan Kemasyarakatan IAIN Syarif Hidayatullah; Jakarta, 2001. 